\title{
Experimental Shear Behavior of Fiber Reinforced Composite Corrugated Plate Girders at Intermediate Supports
}

\author{
O. F. Kharoob, M. F.Hassanein, M. H. Taman and T. E. Abd El-satar \\ Structural Engineering Department, Tanta University, Egypt. \\ omnia_m102010@yahoo.com, fahmi_mostafa@yahoo.com, taman010@yahoo.com, Eng.tamerali2011@yahoo.com
}

\begin{abstract}
:
Bridges with corrugated steel webs have been extensively constructed in different countries. A trapezoidally corrugated steel plate is composed of a series of longitudinal and inclined subpanels. For a steel corrugated web girder, it is assumed that the web carries merely shear forces due to the accordion effect $[1,2]$. The web in such a girder was found to carry insignificant longitudinal stresses from the primary flexure. Consequently, the bending moment is nearly carried by its flanges. Thus, it is worth pointing out that the shear strength can be determined without consideration of moment-shear interaction. But it was found that problem in an area where intermediate supports that shear forces are completely carried by web, and found that the value of the shear resistance, which is a concrete slab by almost be neglected. In recent years has been the study of different types of materials to increase the efficiency of concrete and increase the shear forces at the intermediate supports. Thus in this research, the effect of adding fiber to the concrete in composite corrugated plate girders at intermediate supports was investigated.
\end{abstract}

\section{INTRODUCTION}

In recent years, the use of corrugated plates as webs of girders in bridges and single-story steel buildings has been increased. Considering the significant out-of-plane stiffness of corrugated plates, they have much higher buckling strengths compared to flat web plates. Thus, by using a corrugated plate as a beam web, the necessity of using stiffeners is eliminated and the required web thickness is reduced. Accordingly, they provide relatively high strengthto-weight ratios. These advantages led to the construction of several bridges with corrugated steel web plates [1-5], as shown in Table 1. The most types commonly used for corrugation are trapezoidal, curved [6] and zigzag with the geometric properties shown in Fig. 1.

For a steel corrugated web girder, it is assumed that the web carries merely shear forces due to the accordion effect. Corrugated webs do not carry significant longitudinal stresses from the primary flexure of the girders. Hence, the bending moment can reasonably be assumed to be carried completely by the flanges. As a result, the shear strength can be determined without consideration of moment-shear interaction.
The trapezoidally corrugated steel webs were designed to fail in shear by using enough thick flanges to eliminate the occurrence of the flexural failure mechanism. The experimental program involved the construction; instrumentation and testing of three simply supported trapezoidal corrugated steel webs. The web thickness (tw) was maintained constant for all the girders. Three specimens for beams with $350 \mathrm{~mm}$ depth were tested.

\section{TABLE 1.}

PROFILES OF CORRUGATED STEEL WEBS FOR CONSTRUCTED BRIDGES AND THEIR GEOMETRIC PROPERTIES

\begin{tabular}{|c|c|c|c|c|c|c|c|c|c|}
\hline $\begin{array}{c}\text { Bridge } \\
\text { name }\end{array}$ & $b$ & $d$ & $c$ & $h_{r}$ & $t_{w}$ & $h_{w}$ & $s$ & $\alpha$ & $h_{r} / t_{w}$ \\
\hline Shinkai & 250 & 200 & 250 & 150 & 9 & 1183 & 1000 & 36.9 & 16.7 \\
\hline Matsnoki & 300 & 260 & 300 & 150 & 10 & 2210 & 1200 & 30.0 & 15.0 \\
\hline Hondani & 330 & 270 & 336 & 200 & 9 & 3315 & 1332 & 36.5 & 22.2 \\
\hline Cognac & 353 & 319 & 353 & 150 & 8 & 1771 & 1412 & 25.2 & 18.8 \\
\hline Maupre & 284 & 241 & 284 & 150 & 8 & 2650 & 1136 & 31.9 & 18.8 \\
\hline Dole & 430 & 370 & 430 & 220 & 10 & 2546 & 1720 & 30.7 & 22.0 \\
\hline IIsun & 330 & 330 & 386 & 200 & 18 & 2292 & 1432 & 31.2 & 11.1 \\
\hline
\end{tabular}

$* w$ is the bigger of $b$ and $c$

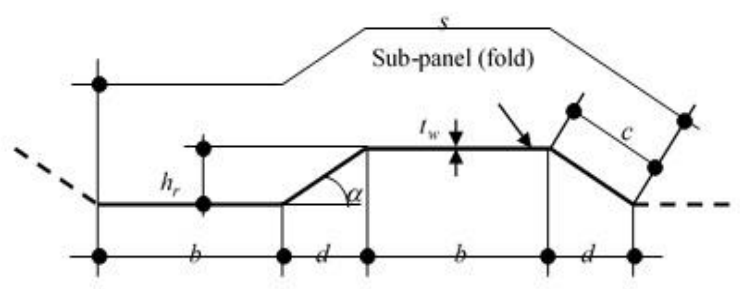

(a) Trapezoidal shape 


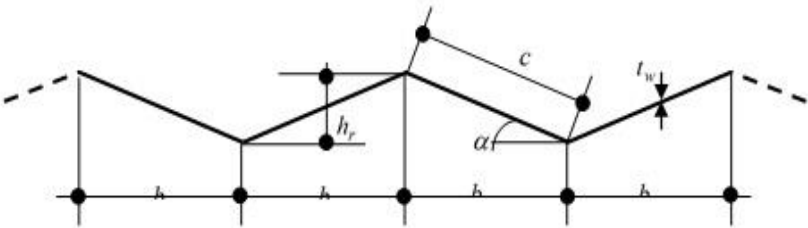

(b) Zigzag shape

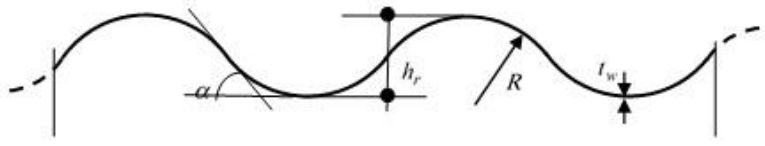

(c) Curved shape

Fig. (1) Corrugation configuration and geometric notation

\section{TEST SPECIMENS}

\subsection{Geometrical details}

As shown above, three specimens of plate girders with trapezoidal corrugated webs were tested to study the shear behaviour of shear beams use fiber-reinforced composite corrugated plate girders using different ratios of fiber used in the concrete while maintaining simply supported under one point loading. It is worth pointing that the load point was not centrally applied with respect to the span. It was shifted to ensure that the failure would occur at the critical panel with the highest values of shearing force in order to eliminate the need for duplicating the instrumentations in both sides of the load applied.

However, all test specimens had the same flange cross section. The width and the thickness of the flanges were fixed to 150 and $14 \mathrm{~mm}$, respectively. It should be noted that the web purely carries shear forces due to the accordion effect $[1,2]$. For that reason, the flanges were maintained constant in the experimental program. The web thickness of all the specimens was $3 \mathrm{~mm}$. Three specimens with $350 \mathrm{~mm}$ depth were used in the experimental program, as shown in Fig. 2. The Profile had the same inclined fold width $(\mathrm{c}=95 \mathrm{~mm})$. The corrugation depth $(\mathrm{hr})$ for profiles $(\mathrm{A})=50$ $\mathrm{mm}$.

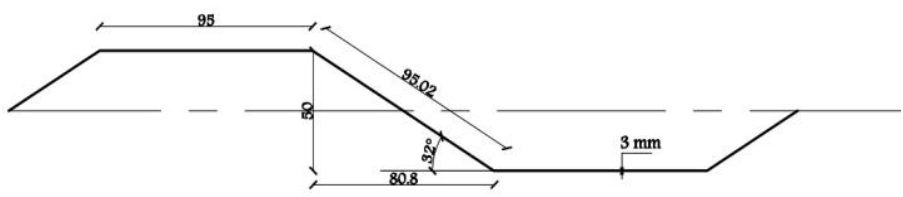

Fig. (2) Corrugated profiles of the specimens

Moreover, Table (2) shows the corrugation configuration and geometric notation. The specimens were labeled such the (hw) could be identified from the label. The label format used is G-hw-C, T, S which T means that concrete slab is in tension $\mathrm{C}$ means that concrete slab is in compression and $\mathrm{S}$ means that steel only, for instance, the label G-350-T represents the plate girder with hw $=350 \mathrm{~mm}$ and the slab of concrete is in tension. However, after the fabrication of the specimens, the actual dimensions of all specimens were measured exactly. Table (3) shows the actual dimension for the specimens.

TABLE 2 .

NOMINAL CORRUGATION DIMENSIONS

\begin{tabular}{|c|c|c|c|c|c|}
\hline $\begin{array}{c}\text { Corrugation } \\
\text { profile }\end{array}$ & $\begin{array}{c}\mathrm{c} \\
{[\mathrm{mm}]}\end{array}$ & $\begin{array}{c}\boldsymbol{h}_{r} \\
{[\mathrm{~mm}]}\end{array}$ & $\begin{array}{c}\mathrm{b} \\
{[\mathrm{mm}]}\end{array}$ & $\begin{array}{c}\alpha \\
{[\circ]}\end{array}$ & $\begin{array}{c}t_{w} \\
{[\mathrm{~mm}]}\end{array}$ \\
\hline (A) & 95 & 50 & 95 & 32 & 3 \\
\hline
\end{tabular}

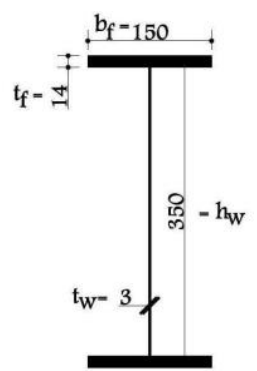

Fig. (3) Cross-sections of the specimens

TABLE 3.

GEOMETRICAL DETAILS OF THE TEST SPECIMENS

\begin{tabular}{|c|c|c|c|c|c|c|}
\hline No. & Designation & $\begin{array}{c}\text { Ratio of } \\
\text { Fiber }\end{array}$ & $\begin{array}{c}\text { End post } \\
(\mathrm{EP}) \\
{[\mathrm{mm}]}\end{array}$ & $\begin{array}{c}\text { Span } \\
{[\mathrm{mm}]}\end{array}$ & $\mathrm{a}$ & $h_{r}$ \\
{$[\mathrm{~mm}]$} & {$[\mathrm{mm}]$} \\
\hline (G7) & G7-350-S & - & 5 & 2100 & 612.5 & 50 \\
\hline (G8) & G8-350-T & Control & 5 & 2100 & 612.5 & 50 \\
\hline (G9) & G9-350-T & Max. fiber & 5 & 2100 & 612.5 & 50 \\
\hline
\end{tabular}

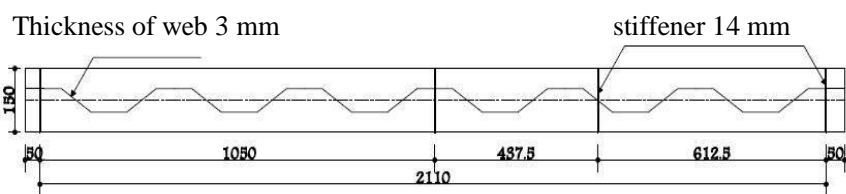

(a) Corrugated profile of the specimens $(\mathrm{G} 7, \mathrm{G} 8, \mathrm{G} 9)$ with $(\mathrm{hw}=350 \mathrm{~mm})$

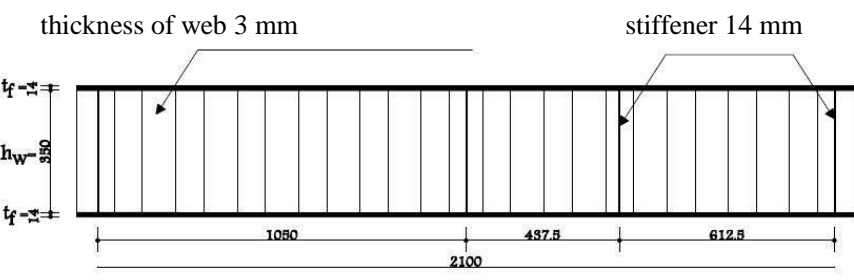

(b) Geometric details of the specimen (G7, G8, G9) with ( hw=350 mm)

Fig. (4) Corrugated profiles and geometric details of specimens (G7, G8, G9)

\section{MATERIAL}

\subsection{Concrete}

Concrete is a construction material composed of Portland cement and water combined with sand and crushed stone. Table (4) shows the concrete mix by weight for one cubic meter. The properties of the used materials in the 
investigation include fly ash (FA), sand as fine aggregate crushed dolomite as a coarse aggregate, a locally produced high range water reducer admixture with a trade name sika viscocrete (3425) was used as superplasticizer and fibers are used in the investigation. The description and specification of these materials are as follows.

TABLE 4.

CONCRETE MIX FOR CASTING SPECIMENS

\begin{tabular}{|c|c|c|c|c|c|c|}
\hline Material & Cement & $\begin{array}{c}\text { Fly } \\
\text { ash }\end{array}$ & $\begin{array}{c}\text { Fine } \\
\text { aggregates }\end{array}$ & $\begin{array}{c}\text { Coarse } \\
\text { aggregates }\end{array}$ & Water & S.P \\
\hline $\begin{array}{c}\text { Weight } \\
(\mathbf{k g}) / \mathbf{m}^{\mathbf{3}}\end{array}$ & 330 & 220 & 800 & 800 & 146.3 & 8.25 \\
\hline
\end{tabular}

\subsubsection{Cement}

Cement is a material, generally, in powder form, that can be made into a paste usually by the addition of water. The most widely used of the construction cement is Ordinary Portland Cement. It is a bluish-gray powder obtained by finely grinding the clinker made by strongly heating an intimate mixture of calcareous and argillaceous minerals. The used cement has a grade of 42.5 MPa. The chemical and physical characteristics of the used cement satisfy the Egyptian Standard Specification No 2421-1993 [7].

\subsubsection{Fly ash}

Class (F) Fly ash (FA), produced in a coal-fired power plant was used in this study. It complies with the chemical and physical requirements of [ASTM C618] [8]. and relevant international quality standards (FA). The chemical composition and physical properties of (FA) according to the manufacturer are given in Table (5). The used FA is obtained from NCC (X-caliber) Company for construction- Egypt.

TABLE 5 .

CHEMICAL COMPOSITION OF FLY ASH

\begin{tabular}{cc}
\hline \hline Component & $\begin{array}{c}\text { Result obtained } \\
\mathbf{\%}\end{array}$ \\
\hline \hline Silica as $\mathbf{S i O}_{2}$ & 49.62 \\
Alumina as $\mathbf{A l}_{2} \mathbf{O}_{3}$ & 20.79 \\
Titania as $\mathbf{T i O}_{2}$ & 1.32 \\
Iron $\mathbf{F e}_{2} \mathbf{O}_{3}$ & 12.71 \\
Calcium as $\mathbf{C a O}$ & 8.3 \\
Magnesium as $\mathbf{M g O}$ & 2.78 \\
Sodium as $\mathbf{N a}_{2} \mathbf{O}$ & 1.62 \\
Potassium as $\mathbf{K}_{\mathbf{2}} \mathbf{O}$ & 1.42 \\
Sulphur trioxide as $\mathbf{S O}_{3}$ & 0.72 \\
Loss on ignition & 0.24 \\
\hline \hline
\end{tabular}

\subsubsection{Fine Aggregate}

The fine aggregate used in the experimental program was natural siliceous sand. Its characteristics satisfy the requirements of [ECP 203/2007]. It was clean and free from impurities with a specific gravity of 2.65 and a fineness modulus of 2.8. The physical and mechanical properties of the used sand are shown in Table (6).
TABLE 6.

\begin{tabular}{cc} 
PHYSICAL AND MECHANICAL PROPERTIES OF SAND \\
\hline Property & value \\
\hline Specific gravity & 2.65 \\
Unit weight $\left(\mathbf{t} / \mathbf{m}^{\mathbf{3}}\right.$ ) & 1.67 \\
Void ratio\% & 36.98 \\
Fineness modulus\% & 2.8 \\
\%clay and fine matter(by weight ) & $1.78 \%$ \\
\hline
\end{tabular}

The grading of the used sand as well as the limits of [ECP 203/2007] [9] is given in Table (7).

TABLE 7.

\begin{tabular}{|c|c|c|c|c|c|c|c|}
\hline \multicolumn{8}{|c|}{ GRADING OF SAND } \\
\hline Sieve size, $\mathbf{m m}$ & 9.75 & 4.75 & 2.36 & 1.18 & 0.6 & 0.3 & 0.15 \\
\hline Passing \% & 99.4 & 97 & 92.7 & 83.25 & 34.3 & 11.5 & 1.62 \\
\hline $\begin{array}{c}\text { \% Passing } \\
\text { ECP [2007] }\end{array}$ & 100 & $\begin{array}{l}89- \\
100\end{array}$ & $\begin{array}{l}60- \\
100\end{array}$ & $\begin{array}{l}30- \\
100\end{array}$ & $\begin{array}{l}15- \\
100\end{array}$ & $\begin{array}{l}5- \\
70\end{array}$ & $\begin{array}{l}0- \\
15\end{array}$ \\
\hline
\end{tabular}

\subsubsection{Coarse Aggregate}

The coarse aggregate used was crushed dolomite, which satisfies the requirements of [ECP 203/2007] [9]. The specific gravity and crushing modulus were 2.6 and $23 \%$ respectively. The delivered crushed dolomite has a maximum nominal size of $10 \mathrm{~mm}$. The physical and mechanical properties of the crushed dolomite are shown in Table (8).

TABLE 8 .

PHYSICAL AND MECHANICAL PROPERTIES OF COARSE

\begin{tabular}{cc} 
AGGREGATE & \\
\hline Property & value \\
\hline Specific gravity & 2.60 \\
Unit weight $\left(\mathrm{t} / \mathrm{m}^{3}\right.$ ) & 1.60 \\
Void ratio\% & 38.5 \\
Crushing $\%$ & 22 \\
clay and fine matter(by weight ) $\%$ & 1 \\
absorption $\%$ & 1.3 \\
\hline
\end{tabular}

On the other hand, the grading, as well as the limits of [ECP 203/2007] [9] for the used aggregate is presented in Table (9).

TABLE 9 .

GRADING OF COARSE AGGREGATE

\begin{tabular}{|c|c|c|c|c|c|c|}
\hline Sieve size (mm) & 37.5 & 20 & 14 & 10 & 5 & 2.36 \\
\hline Passing \% & 100 & 100 & 100 & 97 & 5 & 0 \\
\hline \% Passing ECP [2007] & 100 & 100 & $90-100$ & $85-50$ & $0-10$ & zero \\
\hline
\end{tabular}

\subsubsection{Chemical Admixture}

One type of chemical admixture was used. A high range water reducer (HRWR) (Trade name: sika-viscocrete 3425 produced by Sika company for construction in Egypt) was used as superplasticizer meeting the requirements of [ASTM C494/C494M ] type F \& G. It is a Light yellowish liquid, clear to slightly cloudy having a density of approximately $1.05 \mathrm{~kg} /$ liter at room temperature. 


\subsubsection{Water}

Tap water free from impurities was used for preparing the alkaline solution and mixing according to the requirement of the [ECP 203/2007] [9].

\subsubsection{Steel Reinforcement}

The nominal yield stress of main and secondary steel used in specimens with diameters 12 and $10 \mathrm{~mm}$ was $400 \mathrm{MPa}$, while for special web reinforcement with diameter $8 \mathrm{~mm}$ is $240 \mathrm{MPa}$.

\subsubsection{Fibermesh 300-e3}

The behavior of FRC under loading can be understood from Fig. (5). The plain concrete structure cracks into two pieces when the structure is subjected to the peak tensile load and cannot withstand further load or deformation. The fiberreinforced concrete structure cracks at the same peak tensile load, but does not separate and can concrete structure cracks at the same peak tensile load, but does not separate and can maintain a load to very large deformations. The area under the curve shows the energy absorbed by the FRCs when subjected to tensile load. This can be termed as the post cracking response of the FRCs. as shown in Fig.(5).

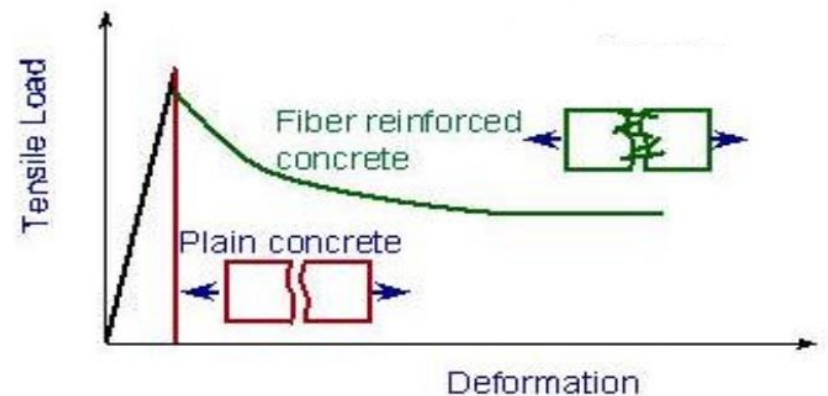

Fig. (5) Tensile Load versus Deformation for plain and fiber reinforced concrete

\subsection{Steel}

The material properties of the specimens were determined by the standard tensile coupon tests. Three tensile tests were conducted to determine the yield stress and Young's modulus of elasticity of the steel used in different components of the plate girder specimens. For each plate thickness used in this experimental program, two tensile specimens were cut and machined. The coupon dimensions conformed to the Egyptian Standard Specification (ESS) for the tensile testing of metals as shown in Fig. (6) as:

The dimensions of the longitudinal coupons are shown in Fig. (6). The coupons were tested according to [10] in UTM displacement controlled testing machine using friction grips. Fig. (8) presents the average stress-strain relationship of the materials. The average yield stress (Fy) and the average ultimate stress $(\mathrm{Fu})$, for each plate thickness, are shown in Table (10).

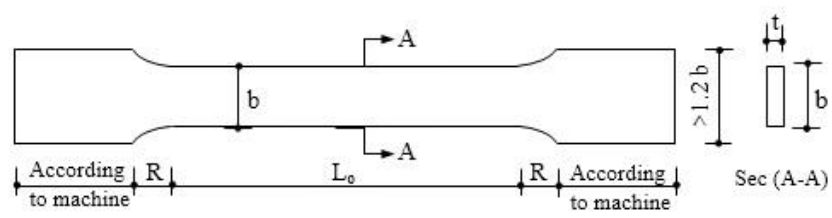

Fig. (6) Tensile coupon test specimen dimensions according to [50]

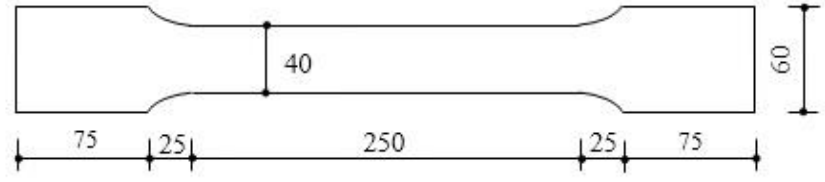

(a) Tensile coupon test specimen of $14 \mathrm{~mm}$ thickness
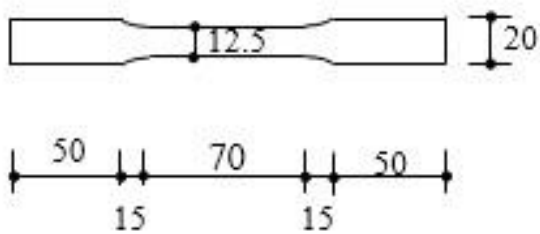

(b) Tensile coupon test specimen of $3 \mathrm{~mm}$ thickness

Fig. (7) Tensile coupon test specimen dimensions in $\mathrm{mm}$

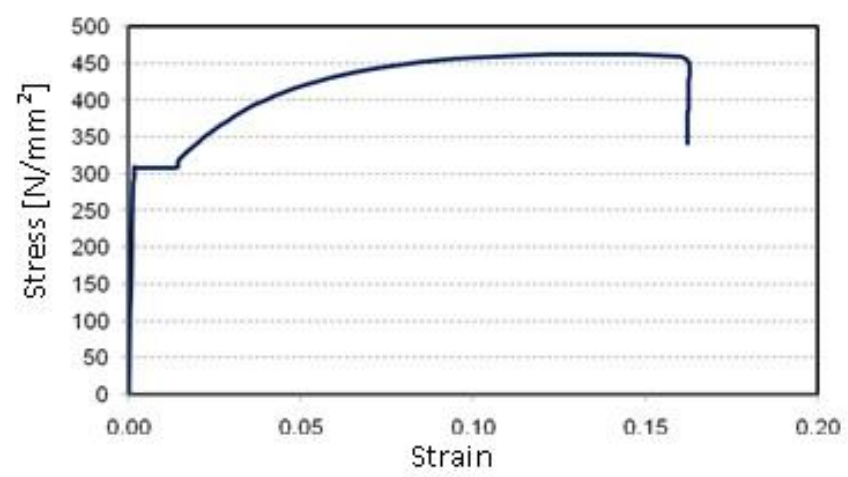

(a) Test specimens of $14 \mathrm{~mm}$ thickness

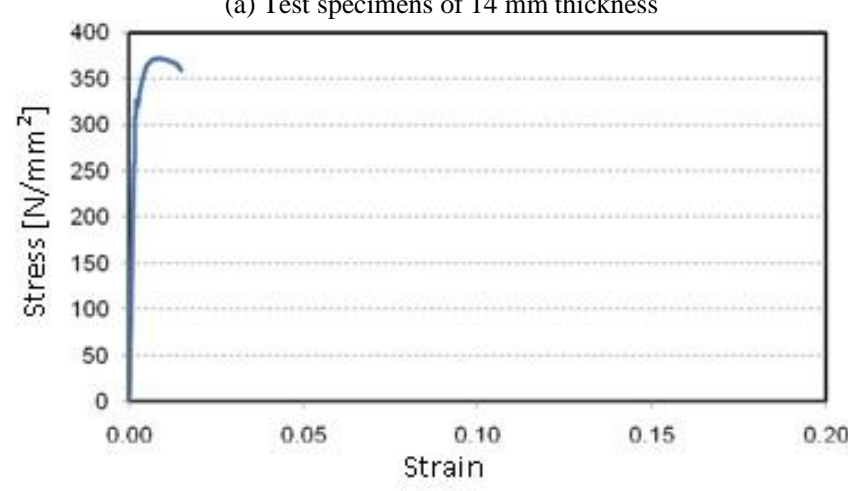

(b) Test specimens of $3 \mathrm{~mm}$ thickness

Fig. (8) Stress-strain curves of steel

TABLE 10.

MEASURED MATERIAL PROPERTIES OF STEEL

\begin{tabular}{|c|c|c|}
\hline $\begin{array}{c}\text { Plate thickness } \\
(\mathrm{mm})\end{array}$ & $\begin{array}{c}\text { Yield stress (Fy) } \\
\mathrm{N} / \mathrm{mm}^{2}\end{array}$ & $\begin{array}{c}\text { Ultimate stress (Fu) } \\
\mathrm{N} / \mathrm{mm}^{2}\end{array}$ \\
\hline 3 & 326.5 & 371.5 \\
\hline 14 & 308.9 & 462.4 \\
\hline
\end{tabular}

\section{TEST SET-UP}

\subsection{Description of the test set-up}

One concentrated point load was applied to the specimens by using a spreader plate. The test arrangement is shown in Fig. (9), Fig. (10). Hinged and roller end conditions were created at the left and the right ends of the specimens, as shown in Fig. (10). 


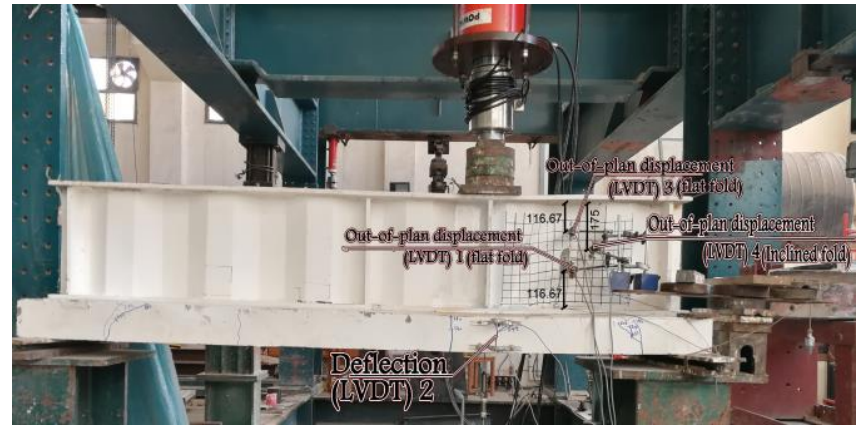

Fig. (9) Test-setup for specimen G8-350-T

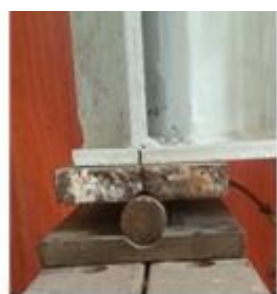

(a) Hinged support

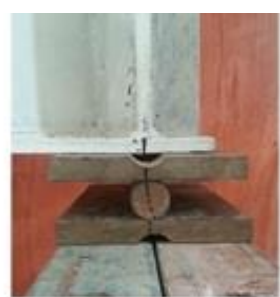

(b) Roller support
Fig. (10) End conditions used in the tests

\subsection{Position of linear variable differential transducers (LVDTs)}

One LVDT was used to measure the vertical deflection of each girder under the applied load $(\delta 1)$ as shown in Fig. (12). Moreover, a three LVDTs were used to measure the out-ofplane displacement one of them is in the center point of the critical panels $(\delta o 1)$, which was set perpendicular to the inclined fold located at the middle of the critical panel and the second one $(\delta \circ 2)$ and the third one $(\delta \circ 3)$. The erected LVDTs are shown in Fig. (13)

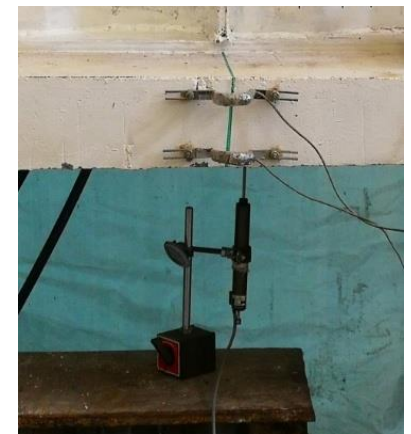

Fig. (11) Positions of LVDT under the applied load $(\delta 1)$ for all specimens

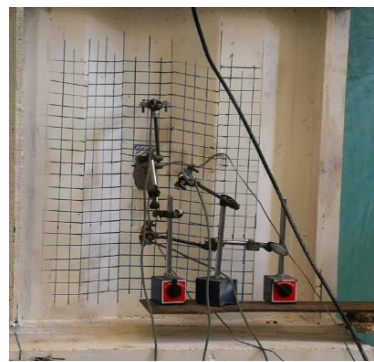

Fig. (12) Positions of LVDTs used to measure the out-of-plane displacement $(\delta \mathrm{o} 1),(\delta \mathrm{o} 2)$ and $(\delta \mathrm{o} 3)$

\subsection{Loading procedure}

Each specimen was painted using whitewash, which was used as an indicator of the pattern of failure. The whitewash was allowed to dry prior to drawing the lines at the fold intersections. The specimen was then ready to be placed in the test frame. A small load was applied to the specimen at the beginning to eliminate any gap that might exist between any of the test components. After that, the dial gauges and the LVDTs were positioned and set to zero before loading started. The concentrated load was applied to the specimens in increments of about $5 \mathrm{kN}$ up to $30 \%$ of the expected design load and then unloaded. After this stage, the load was applied by small load increments until the end of the test. A data acquisition system was used to record the load and the readings of strains and the LVDTs at regular intervals during the tests. Then the specimen was removed and carefully examined after the test.

\section{INSTRUMENTATION}

\subsection{Main test machine}

The steel loading frame, shown in Fig. (13), with a manual jack was used to apply a concentrated load to each specimen. The capacity of the manual jack, applying the concentrated load, is $1000 \mathrm{kN}$. A load cell with a capacity of $900 \mathrm{kN}$ was used, as shown in Fig. (14). to improve the distribution of the load, a spreader plate $(200 \times 200 \mathrm{~mm})$ of $50 \mathrm{~mm}$ thickness was placed between the load cell and the tested specimen. The value of the applied load appeared automatically on a special monitor connected to the load cell all readings were recorded using a data logger as shown in Fig. (15). The test rig is a steel box frame type composed of four columns $5 \mathrm{~m}$ height for each and the beams are $8 \mathrm{~m}$ and $4 \mathrm{~m}$ length and breadth, respectively.

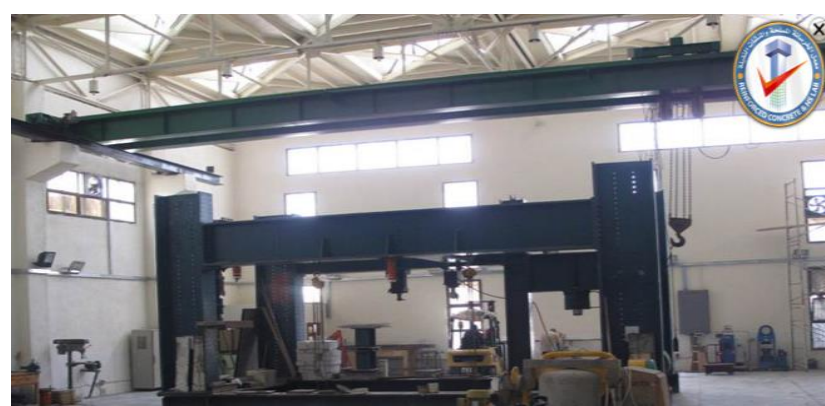

Fig. (13) Testing frame of the RC-Lab
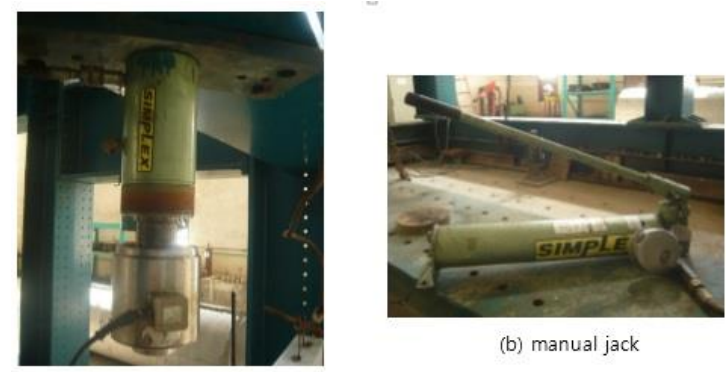

(b) manual jack

(a) Load cell

Fig. (14) Load cell and manual jack 


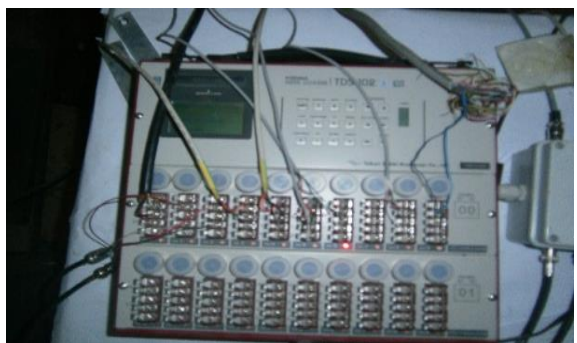

Fig. (15) Data Logger

\subsection{Linear variable differential transducers (LVDTs)}

Three linear variable differential transducers (LVDTs), shown in Fig. (16) were used to measure the out-of-planedisplacement of the web panels. The LVDTs have a maximum reading of $100 \mathrm{~mm}$ with an accuracy of $0.001 \mathrm{~mm}$

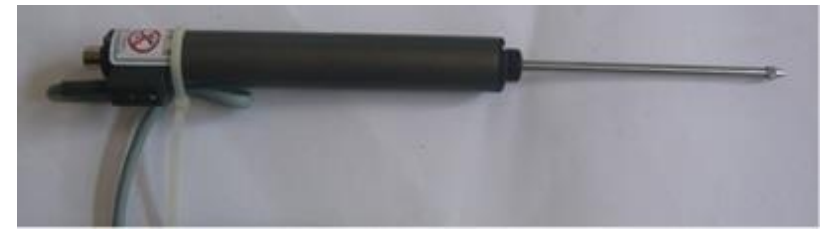

Fig. (16) LVDTS

\subsection{Digital slide calipers}

To measure the web imperfection and the corrugation depth (hr) of each specimen, the digital slide calipers, shown in Fig. (17), was used. The reading accuracy of such calipers is $0.01 \mathrm{~mm}$.

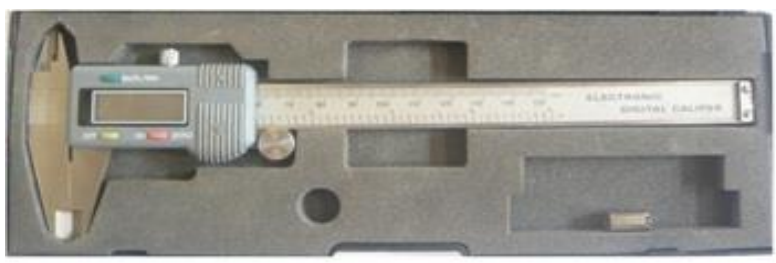

Fig.(17) digital side calipers

\section{TEST REsUlts}

The main objective of the current program is to investigate the effect of the web height (hw) and the fiber in the concrete slab. Therefore, the load-deflection, the load-strain, and the load-out-of-plane displacement curves were plotted for each test specimen.

The effect of the composite can be discussed by comparing specimens G7 (G7-350-S), G8 (G8-350-T-control) and G9 (G9-350-T-max fiber). The load-deflection and the load-Outof-plane displacement $(\delta o 1, \delta o 2, \delta o 3)$ curves are shown in Figs. (18), (19), (20), and (21), respectively. It can be noticed that the strength of the specimen G8-350-T-max fiber is higher than specimen G7-350-S. The maximum deflection $(\delta 1)$ value in specimen $\mathrm{G} 7-350-\mathrm{S}$ is $8.713 \mathrm{~mm}$ at the ultimate load of $484.496 \mathrm{KN}$. The maximum deflection $(\delta 1)$ value of specimen G9-350-T-max fiber is $13.016 \mathrm{~mm}$, at the ultimate load of $584.112 \mathrm{KN}$.

On the other hand, for specimen G8-350-T-control was $14.381 \mathrm{~mm}$ at the ultimate load of $582.414 \mathrm{KN}$. Hence, the percentage of increasing the deflection for specimen G8$350-\mathrm{T}$-control compared to specimen G7-350-S is about $65 \%$ as shown in Fig. (18) and the percentage of increase in the deflection for specimen G9-350-T-max fiber compared to specimen G7-350-S is about $49.4 \%$ as shown in Fig. (18). The percentage of increasing in the ultimate load for specimen G8-350-T-control compared to specimen G7-350$\mathrm{S}$ is about $20 \%$ as shown in Fig. (18) while the percentage of increasing in the ultimate load for specimen G9-350-Tmax fiber compared to specimen G7-350-S is about $20.6 \%$ as shown in Fig. (18).

The increasing of the percentage of the ultimate load for specimen G9-350-T (max. fiber) compared to specimen G8$350-\mathrm{T}$ (no fiber) was $0.29 \%$. Fig. (18) indicates that a strain hardening part occurred for the two specimens after the shear buckling. It can be noticed that the initial stiffness is increased for the specimen G7-350-S than G8-350-T-control and G9-350-T- max fiber. It can be noticed that the toughness values for the specimens G7-350-S, G8-350-T and G9-350-T are $3241.498 \mathrm{KNmm}, 4776.458 \mathrm{KNmm}$ and 4488.07 KNmm, respectively.

Hence, the percentage of increasing in the toughness for specimen G8-350-T-control compared to specimen G7-350$\mathrm{S}$ is about $47.4 \%$ as shown in Fig. (18) and the percentage of increasing in the toughness for specimen G9-350-T-max fiber compared to specimen $\mathrm{G} 7-350-\mathrm{S}$ is about $38.5 \%$ as shown in Fig. (18). the toughness represents the total area under curve. It can be noticed that the ductility is increased for the specimen G8-350-T-control compared to specimen G7-350-S and nearly equal the specimen G9-350-T-max fiber. The percentage of decreasing the toughness for specimen G9-350-T (max. fiber) compared to specimen G8350-T (no fiber) is about $6.42 \%$. Thus, minimum effect was found in the ductility in the case of shallow composite steel corrugated beams.

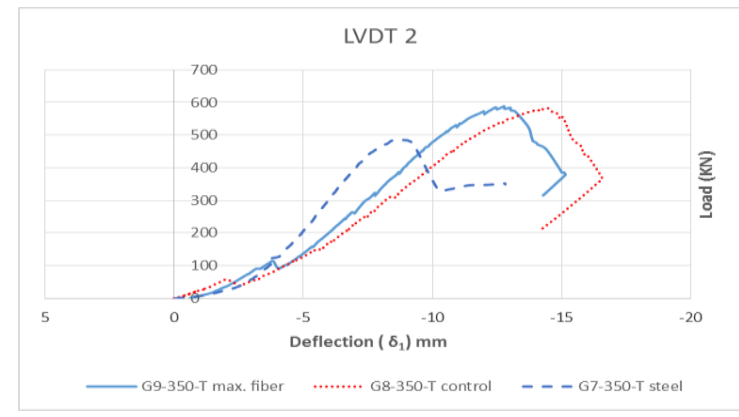

Fig. (18) deflection $(\delta)$ between G7 \& G8 \& G9

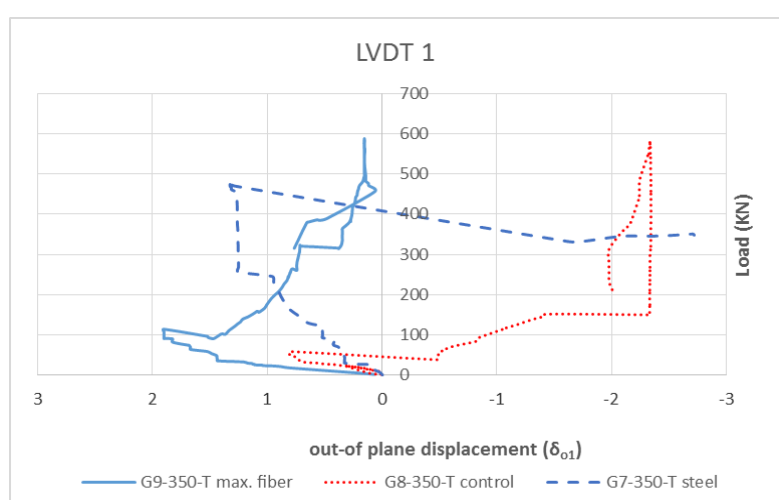

Fig. (19) Out-of-plane displacement ( $\delta$ o1 ) between G7 \& G8 \& G9 


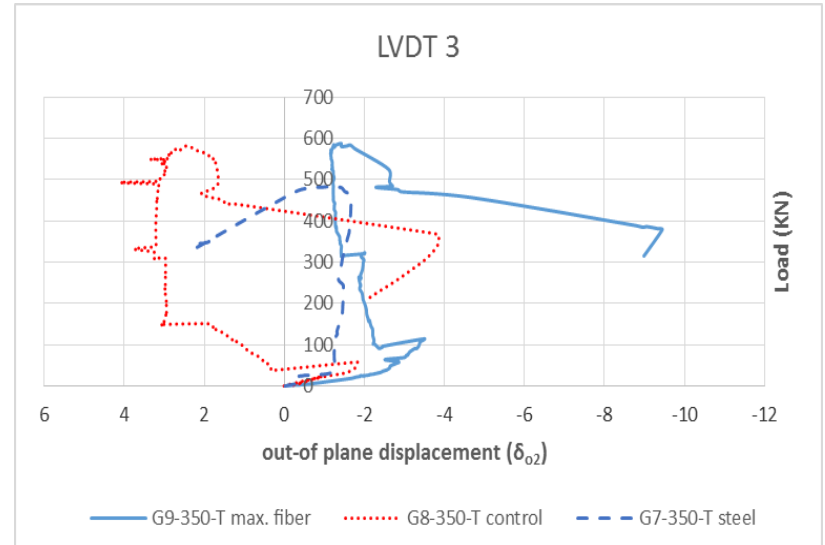

Fig. (20) Out-of-plane displacement ( $\delta$ o2 ) between G7 \& G8 \& G9

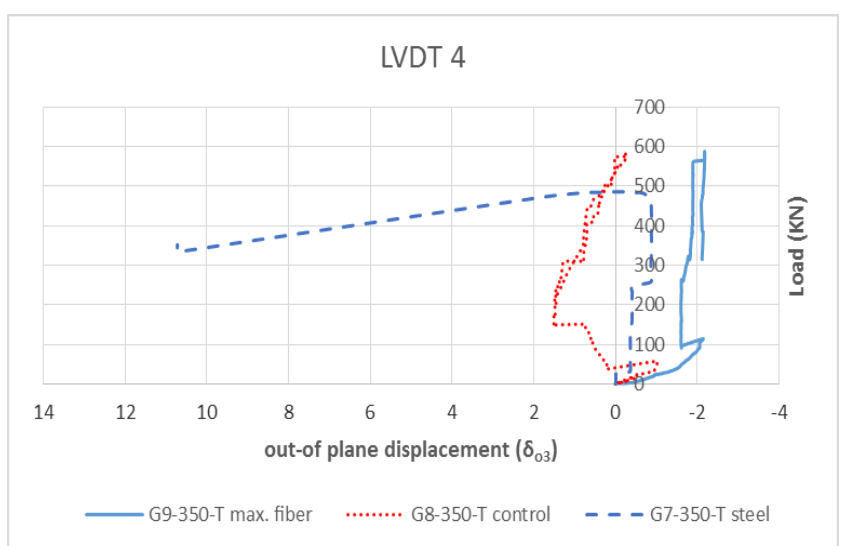

Fig. (21) Out-of-plane displacement ( $\delta \mathrm{o} 3)$ between G7 \& G8 \& G9

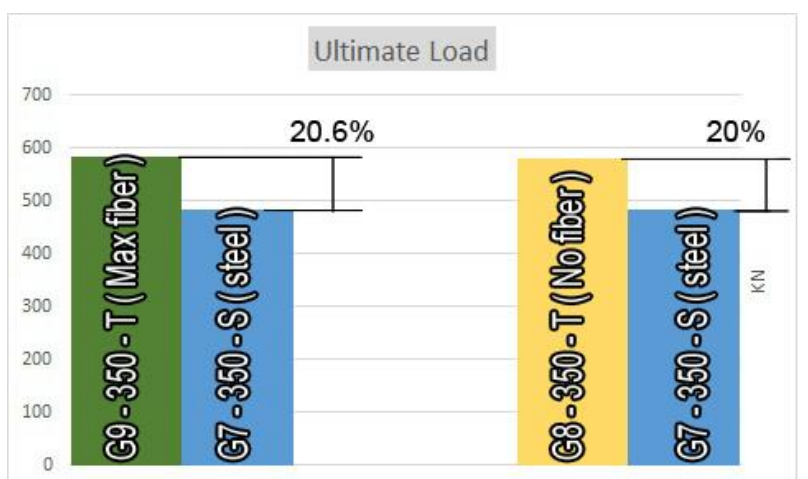

Fig. (22) Test strength for all specimens

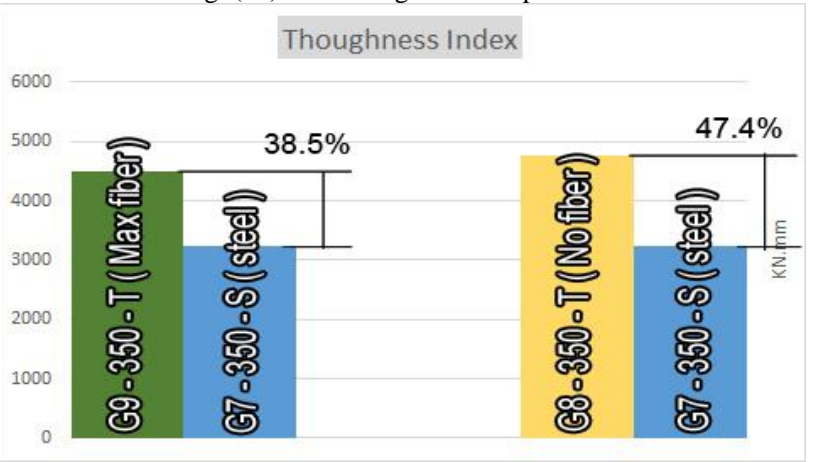

Fig. (23) Test Toughness for all specimens

\section{CONCLUSIONS}

The effect of fiber causes a decrease in the deflection in the shallow composite corrugates steel beam under tension. It was clear that the effect of fiber in the strength of shallow composite corrugated steel beams might be neglected. We recommend using beams with depth more than $350 \mathrm{~mm}$ to see the effect of fiber in the strength and toughness.
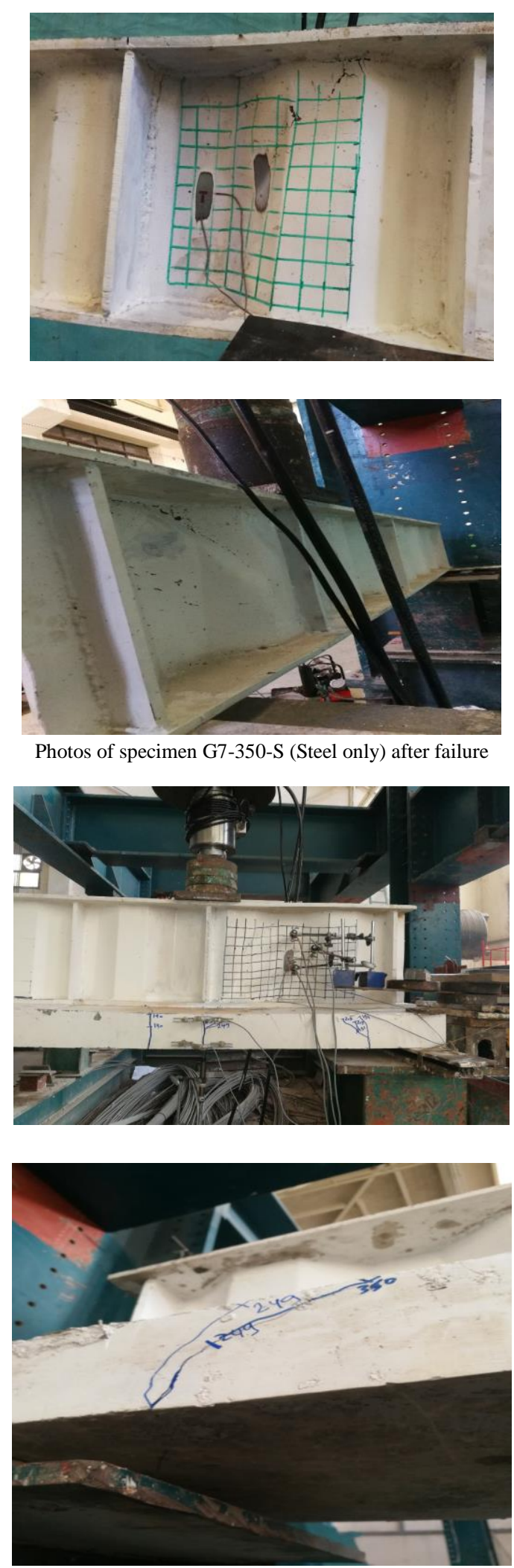

Photos of specimen G8-350-T (no fiber) after failure 

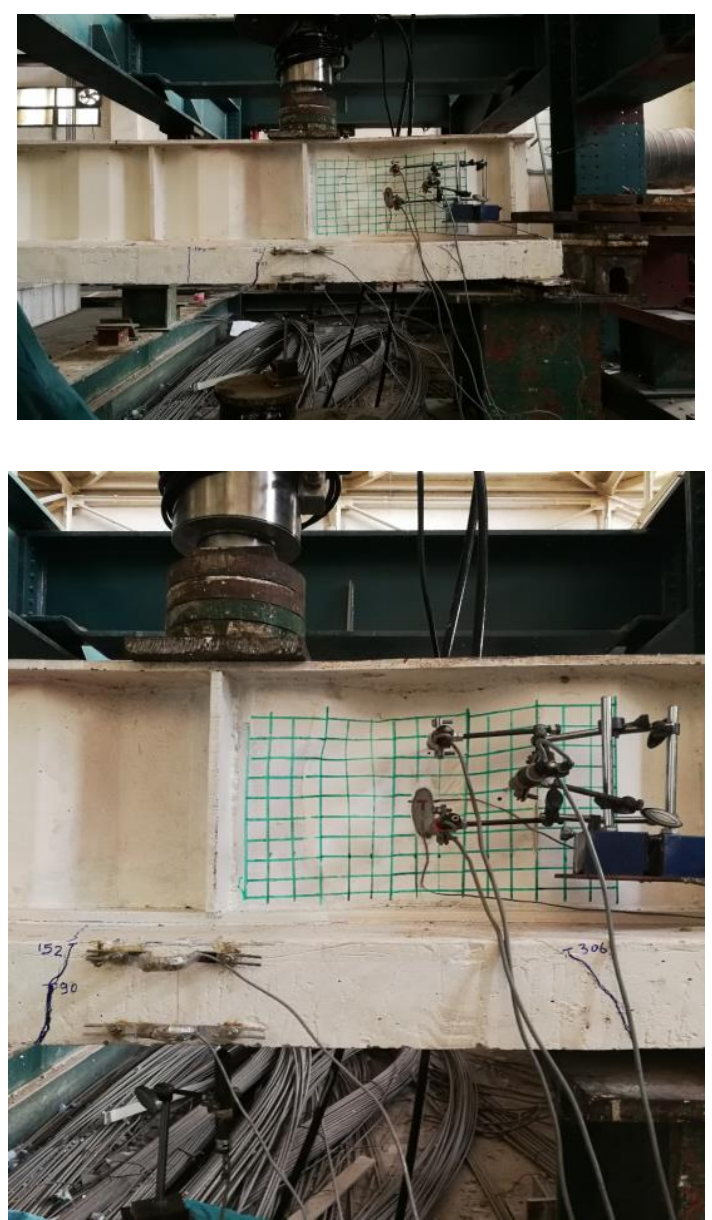

Photos of specimen G9-350-T (max. fiber) after failure

\section{REFERENCES}

[1] Hamilton, R.W., "Behavior of Welded Girder with Corrugated Webs", Ph.D. thesis, University of Maine, 1993.

[2] Driver, RG., Abbas HH., Sause R., "Shear Behavior of Corrugated Web Bridge Girders", Journal of Structural Engineering, ASCE, Vol. 132(2), pp. 195-203, 2006.

[3] <http://en.structurae.de/structures/data/index.cfm?id=s0002973> (accessed (10.02.02)

[4] Yi J, Gil H, Youm K, Lee H. Interactive shear buckling behavior of trapezoidally corrugated steel webs. Eng Struct 2008;30:1659-66.

[5] Moon J, Yi J, Choi BH, Lee H. Shear strength and design of trapezoidally corrugated steel webs. J Constr Steel Res 2009;65:1198-205.

[6] Eldib MEA. Shear buckling strength and design of curved corrugated steel webs

for bridges. J Constr Steel Res 2009;65:2129-39.

[7] Egyptian Standard Specifications No 2421-1993, "Testing of natural and mechanical properties of ordinary Portland cement".

[8] Standard Specification for Chemical Admixtures for Concrete ASTM C494 / C494M

[9] Egyptian Code of Practice: ECP 203-2007, "Design and Construction for Reinforced Concrete Structures," Ministry of Building Construction, Research Center for Housing, Building and Physical Planning, Cairo, Egypt, 2007.

[10] Egyptian standard specification (ESS) 76-1989, for Standard Static Tension Test for Metal. 